\title{
Media, government and the Constitution
}

The PNG Government is trying to 'shoot the messenger'. The danger is that if the Government shoots the messenger today, who will bring them the message they are eagerly looking forward to receiving tomorrow?

\section{By NEVILLE TOGAREWA}

THE CONSTITUTIONAL Review Commission held a four-day public seminar in Port Moresby in January 1996 which addressed, among other issues, 'Freedom of the Press and Media Accountability'. I asked then what the PNG Government meant by media accountabilty. In the six weeks since then nobody has come forward to answer the question.

On the night before the first day of the seminar, I drafted a brief paper which I had hoped I would present at the seminar but I was not given the opportunity to do so. I have since submitted my views to the CRC and had the opportunity to expand on my initial brief submission for this seminar.

I wish to place on record that the views expressed here are mine and do not necessarily represent those of my employer, the Post-Courier, or my colleagues in both the print and electronic media. I am hoping that before the seminar ends, someone in government will tell us the motives behind the National Executive Council decision advising the Governor General to direct the CRC to review the freedom of the Press and media accountability.

I personally believe the decision to review the legal regime vis-à-vis the media was rash, ill-conceived and without justification - a knee-jerk reaction based on the Government's misconceptions of the role and operations of the media. The media directive was no doubt forced on the Government by its failure to financially support its own infomation and communication services to better serve government and the public.

Despite what proponents of the directive will have us - the public - 
believe, there is a misconception by government and the bureaucracy, especially at the executive levels, that there is inherent conflict between the media and government. What the Government may see as conflict is, to journalists, merely the media playing its accepted adversorial and watchdog role. The Government should not misconstrue this as conflict per se.

I don't believe the Government wants a substantive constitutional reform of the media. From conversations I have had with some senior politicians, with secretaries of two key government departments, and with one highly-placed government adviser, I know that the Government is not often concerned about the substance of news stories, a large proportion of which is initiated by the Government itself.

However, I do know that the Government often questions - and is indeed very concerned about - selection and placement of stories. The Government's concern can be adequately dealt with at the management level. This can be done by adopting guidelines to assist editorial committees in selecting and placing stories instead of leaving what are obviously important editorial decisions to a select few who have their own biases and prejudices. Selection and placement of news articles, is, and should remain, the preserve of editorial committees, as is currently the case. They do not call for a Government-sponsored legislative initiative, and they certainly do not warrant a bipartisan-supported constitutional reform of the media.

The Government at times perceives private media companies as public, Government-funded mass media organisations. This is a wrong perception which must be corrected if there is going to be a marked improvement in government-media relations to better serve the public and the nation.

In this regard, it is a shame that successive governments have failed miserably to provide adequate resources financial manpower and equipment to make the National Broadcasting Corporation truly 'The Voice of the Nation'. Successive governments have also failed to adequately fund or make maximum use of what is now the National Communication and Information Office of the Department of the Prime Minister.

Many people, including politicians, criticise journalists. Most of the criticisms, however, are unwarranted. It is obvious that more often than not, the critics are targeting the messenger while they devour the message he brings. In this case, the Government is trying to shoot the messenger. The danger is that if the Government shoots the messenger today, who will bring them the message they are eagerly looking forward to receiving tomorrow?

The Government needs the media to publicise its decisions, disseminate information and get feedback from the public, thereby gauging the mood of the electorate. The media, on the other hand, depends on government for its survival. 


\section{NEVILLE TOGAREWA}

Despite this symbiotic existence, there is a love-hate relationship between government and the media. And so there should be.

Another criticism heard from time to time is that the media is trying to play, or take over, the role of the elected government in setting national agenda, or even running the country. I don't agree with this criticism. A government is made up of supposedly like-minded elected representatives with common philosophies and programs, working in unison to achieve their objectives.

Journalists, on the other hand, are very individualistic, rarely agreeing with each other and collectively, they are very disorganised. This is why the PNG Press Council is defunct; the PNG Journalists Association is defunct; and the PNG Press Club is in hibernation.

Another criticism or misconception by government is that the media is an all-powerful beast prowling Waigani, accountable to nothing and no-one, and a law unto itself. The Prime Minister, Sir Julius Chan, alluded to this when he addressed a luncheon hosted by CRC chairman Ben Micah at Parliament House on 19 December 1995. The Prime Minister said:

(The media) can topple governments, swing votes and destroy a person. I support freedom of the Press ... proprietors and journalists are free to print what they like, but they must be accountable for what they print.

If journalists and the media did have the power to swing notes and topple governments, no government would be in power and no minister would be in office for more than six months. And the Opposition would not have to resort to the vote of no confidence provision, Section 105 of the Constitution because the media would be doing the job for them.

Instead of the government attempting to restrict or regulate the media, it should be enhancing the freedom of the press. In this regard, this seminar should recommend to the CRC to draft a Freedom of Information Bill, based on the United States model, and get Parliament to enact it to allow journalists constitutionally-guaranteed access to National Executive Council records so that the public will know the Government's reasons for issuing the directive on media accountability in the first place.

A Freedom of Information Act will ensure transparency in government decision-making consistent with the democractic principle of honest, open government. The enactment of a Freedom of Information Act is in line with the recommendations of the Constitutional Planning Committee (CPC). Section 46 of the Constitution which gives citizens the freedom of expression and the press should be read together with Section 51 which provides for freedom of information. Section 51 states that 
every citizen has the right to reasonable access to official documents, subject only to the need for such secrecy as is reasonably justifiable in a democratic society in respect of matters relating to national security, defence or international relation, records of meetings and decisions of the National Executive Council and other elected bodies as are prescribed by an Organic Law or an Act of Parliament...

The Government should be reminded about what the CPC said in relation to freedom of information in chapter 5 at page 13 of its report:

For our citizens to be able to participate effectively in the public affairs of this country, it is essential that they have access to official information. Without information as to government activity, a person cannot make a meaningful contribution to discussions of the issues involved in government policies and programs. The degree to which citizens are able to fully participate in debate on the public affairs of the country will be a good measure of the extent to which our system of government is truly democratic.

Governments in many countries fail to communicate effectively to their people the actions they are taking or contemplating, and the problems which face them. Sometimes this is due to a sheer inefficiency on the part of the government information office but sometimes it is a case of the government wanting to keep from the voters the truth about matters which might cause a loss of support for the government if they were widely known ...

We have therefore recommended that a further civil right - that of freedom of access to official documents - be included in the Constitution ... We have further recommended that provisions be made by a law to establish procedures by which citizens may obtain ready access to official documents. It is obviously important that not only the principle of publicity of official documents be firmly established but that the procedures adopted for making that principle effective be simple and widely known.

Governments thus have a vital role to play by ensuring that the public is fully informed. The media's primary commodity is information, but it only sells information. Governments are the producers of information and they are the single largest producers of it. Governments thus have a monopoly over information. They control information, choosing to release that which will enhance their public image, withholding that which may tarnish their imagine, covering up information which could be used to remove them from office, and manufac- 


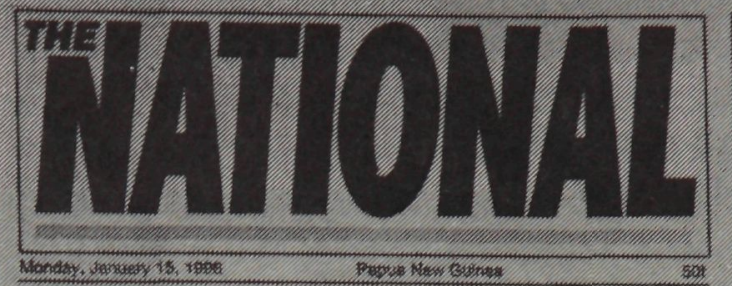

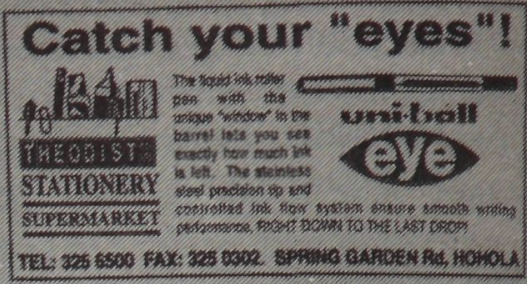
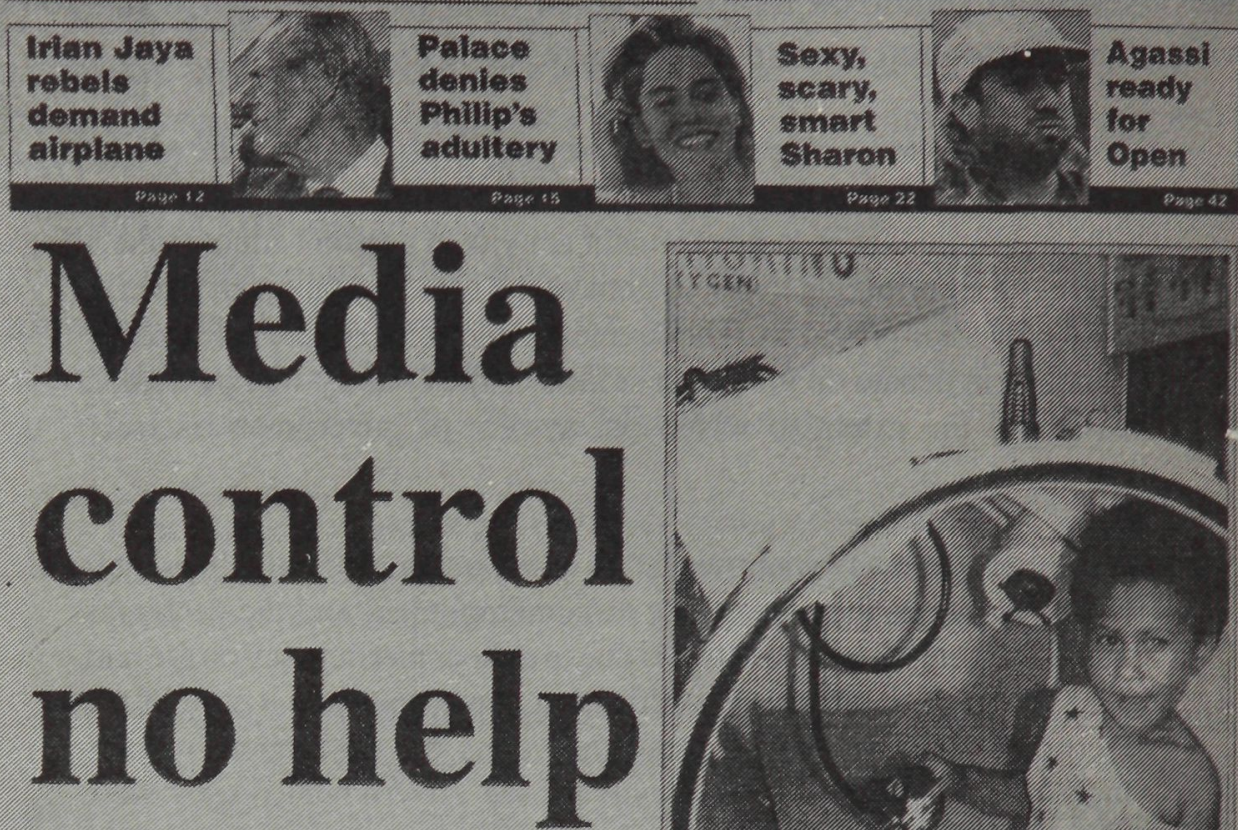

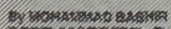

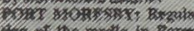

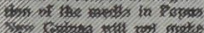

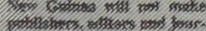

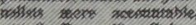

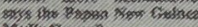
1)

cosusation os whe astia

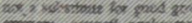

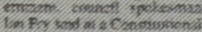

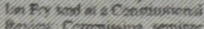

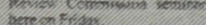
vere $x=5153$

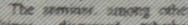

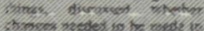

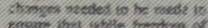

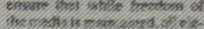

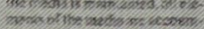

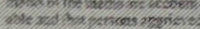

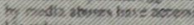
vencoras

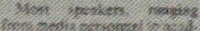

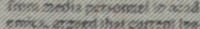

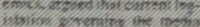

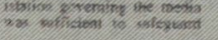

Current laws "are adequate to ensure accountability'

asenecernokes.

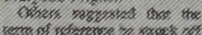

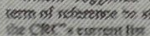

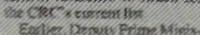

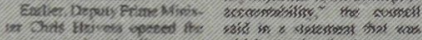

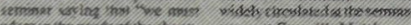

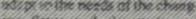

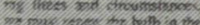

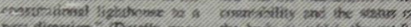

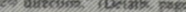

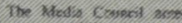

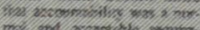

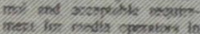
the

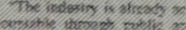

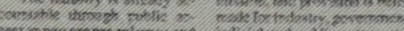

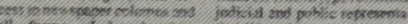

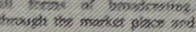

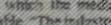

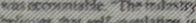

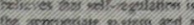

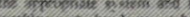

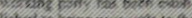

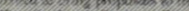
-

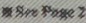

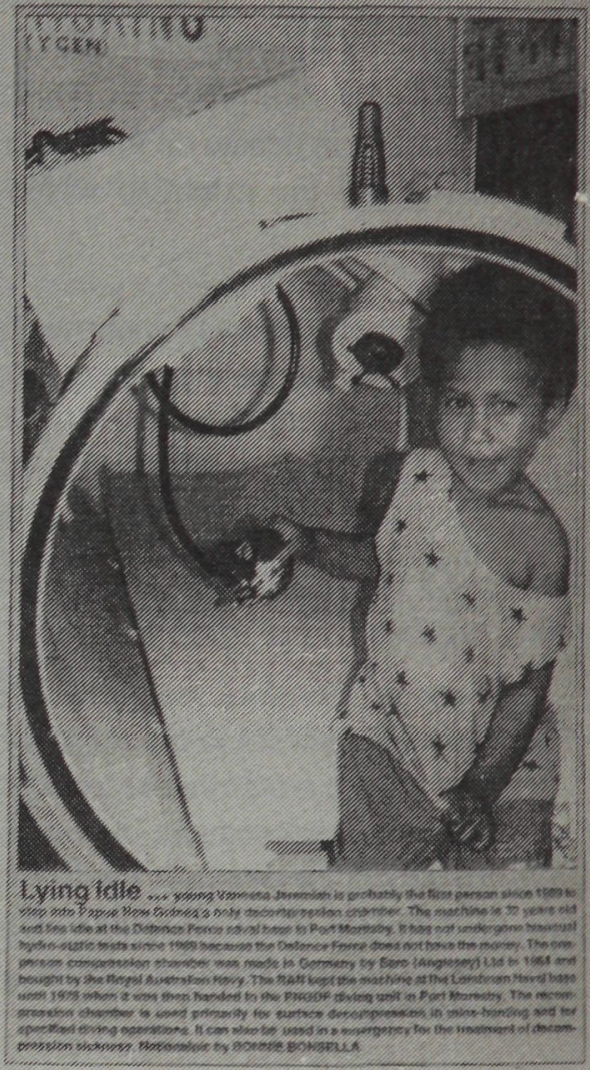

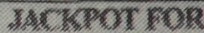

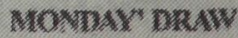
$K 62,000.00$

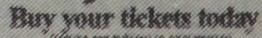

The front page of The National of 15 January 1996. 
turing information through disinformation to achieve a desired objective.

Governments should not monopolise and control information. As elected representatives, ministers who are members of the National Executive Council who make up a government are only trustees, not owners of information. The voters, as owners, are entitled to receive, through the media, information which is correct, complete and on time. It is no accident that the freedom of the press includes the right to receive information. One way of making sure that citizens exercise their constitutional right to receive information without hindrance by government is through a Freedom of Information Act.

The media can be very influential. I agree with the prime minister that the media can destroy a person. I am the first to concede that if a mistake - or a lie as opposed to the truth - is published, the onus is on the newspaper which has published the lie to correct it promptly and give the correction the same prominence as the mistake. I am the first to agree that if I defame someone, I, and my employer, should pay for it.

Journalists are human beings and they make mistakes. They sometimes commit the sins of bias, omission, misreporting, incorrect use of words or phrases, wrong emphasis, invasion of privacy, errors of judgement, misleading headlines and so on. A reporter's greatest enemies are space and time, and he works under varying degrees of deadlines and so on. A reporter's greatest enemies are space and time, and he works under varying degrees of deadline and other pressures every day. But a reporter should not make a mistake and he should never be allowed to make a mistake by reporting a lie with malice and get away with it.

The problem is recognising those mistakes and taking prompt action to correct them. This is where managements of media organsiations can play a vital role in ensuring that, firstly, mistakes are minimised or avoided, and secondly, if a mistake is made, it is corrected forthwith.

I disagree with the criticism that the media is not accountable. The Defamation Act was enacted in 1960 to ensure that the media does not abuse the freedom of the press to crucify individuals. It is the principal mechanism through which aggrieved parties can seek redress.

It is often argued that excessively high legal costs deny aggrieved parties easy access to redress. This is not the fault of the media. Perhaps the Government should address the problem of high legal costs as well. If this cannot be done, the Government should consider using the Public Prosecutor's Office. In this way, more aggrieved parties who simply cannot afford the high legal costs can have free access to redress and the media can be made more accountable for their mistakes.

CRC chairman Ben Micah has gone on record arguing that the Defamation 


\section{NEVILLE TOGAREWA}

Act is out of date and should be amended. It it is the wish of this seminar to strengthen the provisions of the Defamation Act to protect individuals against media abuses, let us do it. But I urge everyone of you to make it your duty to ensure that in the process, we don't unwittingly restrict or regulate the freedom of the press.

I have no doubt that most Papua New Guineans would agree that it is dangerous for any Government to attempt to tamper with the freedom of the press as enshrined in Section 46 of the Constitution or contemplate enacting subordinate legislation to make the media more accountable.

Instead of imposing accountability from the top by restricting or regulating the media by legislation, the best option is for managements of each media organisation to ensure that whatever self-regulatory mechanisms already in place are strictly enforced, and if necessary, new ones added to the list.

Newspapers and television and radio stations have their own internal checks and balances. The objective is to publish fact and not fiction; truth and not lies. Public criticism and costly defamation suits can be minimised or avoided if editorial management teams diligently apply their checks and balances.

Strict adherence to the journalists' code of ethics is one essential element of accountabililty. This is where the PNG Press Council comes in. The council was established in 1985 to help achieve a better industry and promote good relations between the industry and the public. The objective of the Press Council is to act as a guardian of the freedom of the press and a forum to which anyone may make complaints.

The CRC directive on media accountability has prompted serious discussion and action to resurrect the PNG Press Council and rename it the PNG Media Council to include the electronic media under its jurisdiction. This is welcome news indeed. The council should, as a matter of priority and good business practice, strictly enforce the journalists' code of ethics if it is to achieve its aims of improving ethical and professional standards, achieving a better industry and maintaining good relations with the public.

Training is one area that must be addressed. A journalist who has received inadequate training is more likely to make a mistake than one who is well trained. A journalist, like any other professional or tradesman, needs the right tools of his profession. This is done, initially, by formal training ending in a diploma or degree, or through a cadetship.

Most journalists would argue, however, that they are not receiving adequate on-the-job training. It is the responsibility of the employer to provide on-going training to give reporters the necessary skills to competently and confidently do their job. 
The onus is equally on government to train journalists by allocating sufficient funds every year to the school of journalism at the University of Papua New Guinea and the Divine Word Institute in Madang. Government should also provide adequate funds for regular seminars, workshops and scholarships for further training at home and abroad. In this regard, successive governments have failed very badly.

A degree or diploma course or a cadetship, however, can only provide an aspiring reporter with limited skills. There is no substitute for hard work, commitment to the profession and experience which, collectively, can make a journalist worthy of being called a professional.

As professionals, are reporters receiving adequate remuneration? There has been a brain drain from the media industry over the years. Experienced reporters have left to take up better offers in the private sector. Some have left mainstream journalism to take up jobs with commercial statutory authorities and the Government.

Most of the stories you read in your newspapers, see on your TV screens and hear on your transistor radios every day are written by junior and inexperienced reporters. In fact, no newsroom can boast of having more than a handful of experienced professional reporters. Conditions of employment is therefore another area which should be addressed. Again, this question can best be answered by management.

Reporters, like all human beings, have their biases too which surface from time to time in the stories they write. Discerning newspaper readers, television viewers and radio listeners can identify such biases as and when they occur.

What most people don't know is that journalists are also accountable to their conscience through self-censorship. In the course of their work, reporters are sometimes told or they come to personally know which leader, for example, is being unfaithful to his spouse or has done or is doing certain things which, if exposed, could be very damaging to him personally and to the office he holds.

In case a leader pleads privacy in defence, I would refer him to what John Gawi said about politicians, the freedom of the press and accountability at the constitutional seminar in January.

The point I wish to make here is that there is an imaginary fence or boundary which we, as photographers and journalists, do not jump over or cross. Our leaders should be grateful that our photographers are not paparazzi; that our journalists do not subject them to more stringent public scrutiny by hounding them 24 hours a day like our foreign counterparts do to their leaders, pop stars, members of the royal family and other VIPs.

Should journalists censor themselves under these circumstances? Is it ethical and in the public interest for journalists to do so? Does the fact that leaders 


\section{NEVILLE TOGAREWA}

have made a conscious decision to live in glass houses demand that they be subject to much more stringent public scrutiny than they are getting now?

Perhaps the best way to begin to answer these and other equally pertinent questions and to tackle the issue of media accountability generally is to pose the question: Do newspapers and other mass communications media have a wider responsibility to the community? Again, it is up to the managements of each media organisation to ask themselves this question, do some soul-searching and come up with some honest answers.

There is one thing that the media and Government agree on. Journalists, editors and chief executives of media organisations acknowledge that the media is an important tool of nation-building. However, the media's potential as a tool of development can only be realised if the government of the day makes it possible. The way to go about doing this is not by legislating to restrict or regulate the freedom of the press and make the media more accountable but by enhancing the freedom ofthe press.

Someone once declared: The press is a cornerstone of democracy. And someone once said: A house divided will not stand. I hope and pray that the Government is not trying to dislodge one of the cornerstones of our democracy, and I hope and pray that the Government is not attempting to crack the foundation of the People's House.

I wish to ask Prime Minister Sir Julius Chan and each of his cabinert ministers who were party to the CRC directive on media accountability: Are your intentions honourable? If your intentions are indeed honourable, we, the people of Papua New Guinea who have given you the mandate have the right and are entitled to know. But if your intentions are not honourable, God protect Papua New Guinea.

$\square$ Neville Togarewa is a senior journalist of the Post-Courier and a member of the editoriai board of PJR. He presented this paper at the 'Freedom at the Crossroads' seminar in Port Moresby, 29 February-1 March 1996. 